Saúde, Ética \& Justiça, 4(1/2):65-6, 1999.

\title{
TransPLANTE hepÁtico: VALOR DO CONSENTIMENTO PÓS-INFORMADO A LUZ DOS ASPECTOS AFETIVOS DOS DOADORES VIVOS NO PERÍODO PRÉ-OPERATÓRIO
}

\author{
Rita de Cássia RODRIGUES ${ }^{1}$
}

Rodrigues, R.C. Transplante hepático: valor do consentimento pós-informado à luz dos aspectos afetivos
dos doadores vivos no período pré-operatório. São Paulo, 1999. 124p. Dissertação (mestrado) -
Faculdade de Medicina da Universidade de São Paulo. Saúde, Ética \& Justiça, 4(1/2):65-6, 1999. [Resumo]

Resumo: Introdução: a legislação e o Código de Ética Médica brasileiros regulamentam as cirurgias de transplantes. O doador vivo deve ser informado sobre os riscos e os benefícios do processo. Após a etapa consentem ou não a cirurgia através do termo de consentimento pós-informado. Mas, estão estes pais competentes para compreenderem as informações? Duas correntes de pensamento definem competência: 1. É uma habilidade cognitiva: entender e avaliar; 2. É uma condição para posicionar-se entre a emoção e a razão. O que determina a competência? A razão? A emoção? Ao se compreender o funcionamento de sua vida psíquica compreende-se o que é ser competente nesta situação? Objetivo: avaliar a influência do contéudo emocional dos pais na competência para assinarem o termo de consentimento pós-informado. Método: uma ou duas entrevistas psicológicas antes da operação com os doadores, aos quais foi solicitado que fizessem o desenho de uma figura humana. Após a cirurgia a evolução psicológica dos pais foi avaliada através do acompanhamento psicológico e, aproximadamente dez dias depois, foi novamente solicitado que fizessem o desenho de uma figura humana. Casuística: seis pais doadores para seus filhos: cinco mães e um pai. A média de idade dos pais foi de 35 anos. Cinco dos receptores tinham idades entre um ano e seis meses a três anos. Um receptor com onze anos. Três doadores completaram o curso superior, dois completaram o segundo grau e um não completou o ginásio. Resultados: o conteúdo emocional de cinco dos seis pais, determinou as doações. Uma mãe decidiu ser a doadora após compreender e assimilar as informações sobre os riscos e benefícios do processo. Três mães não compreenderam e não assimilaram as informações fornecidas. Um pai e uma mãe compreenderam e assimilaram as informações dadas, nãs as consideraram para a decisão de ser doador; o pai porque acreditava que a vida do filho era mais importante que a sua e a mãe porque acreditava que Deus a protegeria de qualquer risco. A vivência da realidade do período pós-operatório possibilitou a revisão das fantasias apresentadas antes da operação. Cinco pais redimensionaram os conflitos em relação aos fiIhos. Uma mãe evoluiu com dificuldades para elaborar o seu processo cirúrgico. Conclusão: a competência depende do estado emocional; os conflitos da vida psíquica do doador determinam a sua escolha.

Unitermos: Transplante de fígado/psicologia. Transplante de fígado/legislação \& jurisprudência. Competência mental/ psicologia. Doadores vivos/psicologia. Consentimento esclarecido/legislação \& jurisprudência. Entrevista psicológica/ métodos. Cuidados pré-operatórios/psicologia.

1 Psicóloga. Mestre em Ciências (Medicina Legal) pela Faculdade de Medicina da Universidade de São Paulo. Endereço para correpondência: Rua Teodoro Sampaio, 115. 05405-000. São Paulo, SP. 
Rodrigues, R.C. Liver transplantation: informed consent value in relation to liver donnor's affective aspects during pre-operative period. São Paulo, 1999. 124p. Dissertação (mestrado) - Faculdade de Medicina da Universidade de São Paulo. Saúde, Ética \& Justiça, 4(1/2):65-6, 1999. [Abstract]

\begin{abstract}
The transplantation surgeries in Brazil are ruled by brazilian civil law and the Code of Medical Ethics. The living donor shall be informed about the risks and benefits of the operation and after that he consent or not to be a liver donor. Are these parents competent to understand the informations? Two ways of thinking define competence: 1 . It is a cognitive hability: understand and evaluate; 2 . It is a condition to be between emotion and reason. What determines competence? The reason? The emotion? To comprehend the donnor's ways of their psychique life permits us to comprehend what is to be competent in this situation? Objective: To verify the influence of emotional aspects of parents living donors on competence to sign the informed consent. Method: One or two psychological interviews with parents before operation when they were asked to draw a human figure; psychological follow-up of approximately 10 days after surgery, the time when they were asked again to draw a human figure. Casuistic: Six parents, five female
\end{abstract}

and one male with mean age of 35 years; three of them had graduated on an university course, tree had graduated on high-school and one had not finished high-school. The age of five receptors varied from one year and six months to three years and one of them was eleven years old... Results: The emotion determined the donation in five out of six parents... One mother decided to be liver donor after understanding the risk/benefit informations; three mothers coudn't understand the given informations; the father and one mother understood all informations but didn't give attention to them: the father believed his son's life was more important and the mother believed God would protect her from any risk. The postoperative period experience permited to revise the fantasies stated before surgery... Five parents reviewed their conflicts with their sons. It was dificult to one mother to supplant her surgical process. Conclusion: The competence depends on emotional state; donors menthal life conflicts determine their choice...

Keywords: Liver transplantation/psychology. Liver trasnplantation/legislation \& jurisprudence. Mental competency/ psychology. Living donors/psychology. Informed consent/legislation \& jurisprudence. Interview, psychological/methods. Preoperative care. 